\title{
Людмила Душик
}

кандидат медичних наук, кафедра хірургічних хвороб, Харківський національний

університет ім. В. Каразіна; Харків, Україна

ORCID: 0000-0002-8330-7221

E-mail: dushiklyudmila@gmail.com

\section{Валентина Михайличенко}

кандидат філософських наук, профессор кафедри педагогіки і психології управління соціальними системами ім. академіка I. Зязюна,

Національний технічний університет "Харківський політехнічний інститут”; Харків, Україна

ORCID: 0000-0001-7390-5319

E-mail:valentina_be@ukr.net

\section{Олексій Цівенко}

доктор медичних наук, професор кафедри хірургічних хвороб, Харківський національний університет ім. В. Каразіна; Харків, Україна

ORCID: 0000-0003-0839-9768

E-mail: olexiy.i.tsivenko@karazin.ua

\section{СИМУЛЯЦЙНЕ НАВЧАННЯ У ПІДГОТОВЦІ МАЙБУТНІХ ЛІКАРІВ ЯК СПОСІБ РОЗВИТКУ ЇХНЬОГО ПРАКТИЧНОГО ДОСВІДУ}

Анотація: показано, що використання симуляційних технологій у процесі навчання дозволяє студентам-медикам набувати практичного досвіду і якісно підвищувати рівень свого професіоналізму на тлі належного рівня теоретичних знань. Розглянуто зміст симуляційного навчання як мистецтва імітувати реальність, послідовність подій і дій або розумовий процес навчання якісному наданню медичної допомоги пацієнтам. Розкрито його переваги та недоліки. Проведено аналіз ефективності симуляційного тренінгу 3 залученням стандартизованого “пацієнта" під час проходження практики студентами кафедри хірургічних хвороб. Показана роль викладачів кафедри, що спостерігали за поведінкою “стандартизованого пацієнта" і оцінювали результати роботи студентів за бальною системою, відповідно до критеріїв. Проведено детальний розбір результатів тренінгу, спільне обговорення заходів, спрямованих на покращення лікувальнодіагностичної тактики та отриманих помилок. Розроблені методичні рекомендації проведення тренінгу. Зроблено висновок, що метод “стандартизованих пацієнтів" $\epsilon$ ефективним способом набуття практичного досвіду клінічної компетентності та ії оцінки. Світове поширення цього методу свідчить про необхідність його інтенсивного впровадження в Україні.

Ключові слова: медична освіта, симуляційне навчання, “стандартизований пацієнт”, студент, хірургічне лікування, майбутні лікарі, тренінг, результати, практичні навички.

(C) Людмила Душик, Валентина Михайличенко, Олексій Цівенко, 2021 


\section{Liudmyla Dushyk}

candidate of medical sciences, department of surgical diseases, Kharkiv National

University V. Karazin; Kharkiv, Ukraine

E-mail:dushiklyudmila@gmail.com

\section{Valentina Mykhaylychenko}

candidate of philosophical sciences, professor, department of pedagogy and psychology management of social systems, academician I. Zyazyun, National Technical University

"Kharkiv Polytechnic Institute"; Kharkiv, Ukraine

E-mail:valentina_be@ukr.net

\section{Olexii Tsivenko}

doctor of medical sciences, professor, department of surgical diseases,

Kharkiv National University V. Karazin; Kharkiv, Ukraine

E-mail: olexiy.i.tsivenko@karazin.ua

\section{SIMULATION TRAINING IN THE FORMATION OF FUTURE DOCTORS AS A WAY OF DEVELOPING THEIR PRACTICAL EXPERIENCE}

Abstract: it is shown that the use of simulation technologies in the learning process allows medical students to gain practical experience and qualitatively increase the level of their professionalism against the background of the appropriate level of theoretical knowledge. The content of simulation training as an art to imitate reality, the sequence of events and actions or the mental process of training in the quality of medical care to patients is considered. Its advantages and disadvantages are revealed. An analysis of the effectiveness of simulation training with the involvement of a standardized "patient" during the internship by students of the Department of Surgical Diseases. The role of teachers of the department is shown, who observed the behavior of the "standardized patient" and evaluated the results of students' work according to the scoring system, according to the criteria. A detailed analysis of the training results, a joint discussion of measures aimed at improving treatment and diagnostic tactics and errors were conducted. Methodical recommendations for training have been developed. It is concluded that the method of "standardized patients" is an effective way to gain practical experience of clinical competence and its evaluation. The worldwide spread of this method indicates the need for its intensive implementation in Ukraine.

Key words: medical education, simulation training, "standardized patient", student, surgical treatment, future physicians, training, results, practical skills.

\section{Людмила Душик, Валентина Михайличенко, Алексей Цивенко}

\section{СИМУЛЯЦИОННОЕ ОБУЧЕНИЕ В ПОДГОТОВКЕ БУДУЩИХ МЕДИКОВ КАК СПОСОБ РАЗВИТИЯ ИХ ПРАКТИЧЕСКОГО ОПЫТА}

Аннотация: показано, что использование симуляционных технологий в процессе обучения позволяет студентам-медикам приобретать опыт практической работы и качественно повысить уровень своего профессионализма на основе достаточного уровня теоретических знаний. Рассмотрено суть метода как искусства имитировать реальность, 


\section{МАЙСТЕРНОСТІ МАЙБУТНІХ ФАХІВЦІВ}

последовательность событий и действий или мыслительный процесс обучения качественному оказанию медицинской помощи пациентам. Раскрыто его преимущества и недостатки. Проведен анализ єффективности симуляционного тренинга с использованием “стандартизованого пациента” во время прохождения практики студентами кафедры хирургических заболеваний. Показана роль преподавателей кафедры, которые наблюдали за поведением “стандартизованного клиента" и оценивали результаты работы студентов с помощью балльной системы соответственно критериев. Проведен детальный обзор результатов тренинга, совместное обсуждение способов, направленных на улучшение лечебно-диагностичной тактики и допущенных ошибок. Разработаны методические рекомендации проведения тренинга. Сделан вывод, что метод “стандартизованных пациентов” является эффективным способом приобретения практического опыта лечебной компететности и её оценки. Его распространение во всем мире говорит о необходимости его интенсивного внедрения в Украине.

Ключевые слова: медицинское образование, симуляционное обучение, “стандартизованный пациент”, студент, хирургическое лечение, будущие врачи, тренинг, результати, практические навыки.

\section{Liudmyla Dushyk, Valentina Mykhaylychenko, Olexii Tsivenko}

\section{An extended abstract of the paper on subject of: \\ "Simulation training in the formation of future doctors as a way of developing their practical experience"}

Problem setting. It is shown that the main goal of higher education today is successful implementation of acquired knowledge and skills in future professional activities and directing the graduate to selfeducation, self-development and self-help. This is possible only as a result of students' self-directed work in the learning process at HEI by means of effective pedagogical technologies of self-education.

Recent research and publications analysis. The essence of simulation as art is to simulate reality, sequence of events and actions or intellectual process of teaching quality medical care to patients. It is shown that the use of simulation technology in the learning process allows medical students to gain experience in practical work and competently raise the level of their professionalism on the basis of sufficient level of theoretical knowledge. The analysis of efficiency of simulation training with the use of "standardized patient" during the practical training of students of the department of surgical diseases of Karazin Kharkiv National University was carried out.
Paper objective. Before the training most of the students had very low marks concerning theoretical questions $170 \%$ didn't give $60 \%$ of correct answers, $15 \%$ gave right answers in less than $50 \%$ correlation, and only $15 \%$ demonstrated good and excellent knowledge). According to the questionnaire at the end of the training, the biggest difficulties were experienced by prospective doctors during the examination (36.4\%), differential diagnosis of the disease (22\%) and during the preparation of the treatment programme (40\%). The university graduates themselves considered the reasons for these circumstances in the lack of their own theoretical knowledge (54\%) and that stimulation training in clinical diagnostics and pharmacotherapy of surgical diseases helped the future physicians to master the knowledge and skills of 72,3\%.

Paper main body. A detailed review of the results of the training was carried out as well as a joint discussion of the methods aimed at improvement of the treatment and diagnostic tactics as well as of the admissible errors. The value of the method 
"Standardized Patient", its advantages and disadvantages are shown. Identified problems that need to be solved for successful and effective implementation of simulation training in medical education. It was concluded that only the presence of simulators is not enough to ensure high quality of practical training for listeners. Need to use certain pedagogical technologies that ensure continuity of the system of correction and improvement of practical skills and training to perform professional activities at all stages of training of the listener.

Shown the role of chair teachers, who monitored the behavior of "standardized client" and evaluated the results of the work of students by means of a ballot system according to the criteria. They evaluated consistency, comple-teness and quality of actions of the student during scans, anamnesis, physical examination, adequacy of analysis of data of additional methods of examination and tactics of the further

Постановка проблеми в загальному вигляді та іiі зв'язок із важливими науковими чи практичними завданнями. Головною метою вищої освіти сьогодення стала успішна реалізація отриманих знань і умінь майбутньої професійної діяльності та спрямування випускника на самоосвіту, само розвиток і самовдосконалення. Це можливо лише як результат самостійної роботи студентів під час навчання у $3 \mathrm{BO}$ за допомогою ефективних педагогічних технологій самоосвіти. Вона повинна бути індивідуалізованою 3 урахуванням рівня творчих можливостей студента, його навчальних здобутків, інтересів, активності.

Ключовим детермінантом модернізації вищої медичної школи $\epsilon$ відповідність вимогам практичної сфери охорони здоров'я населення 3 урахуванням інтеграції у європейський простір вищої освіти. Ці напрями декларуються в усіх документах, що визначають зміст реформи вищої медичної школи в Україні на treatment of the patient. The usefulness of the discussion on the introduction of "standardized patient" is given. It is proved that the method of "standardized patients" is an effective way to gain practical experience of treatment competence and its evaluation.

Conclusions of the research. It was concluded that in the light of current problems of current health care is obvious that you need not only actively look for new ways to improve the quality of education of physicians, but also more widely implement promising innovations in the structure of the educational and methodological process. Particular attention should be given to the methods of active learning and control, which are the most effective and efficient. At the same time, they are by no means opposed to modern clinical training of students. Only their adequate combination can realistically improve the educational level of graduates of higher medical institutions, and provide practical health care to highly qualified professional.

сучасному етапі. Розвиток національної системи охорони здоров'я $\epsilon$ неможливим без підготовки нового покоління висококваліфікованих медичних працівників, подальшого впровадження інноваційних технологій навчання та форм організації навчального процесу з урахуванням традицій вітчизняної вищої медичної школи та процесу інтеграції національної вищої освіти до Європейського освітнього простору.

Класична система клінічної медичної освіти не здатна в повній мірі вирішити проблему якісної практичної підготовки лікаря. Пріоритетним напрямком вищої медичної освіти в сучасних умовах $є$ посилення аспекту оволодіння мануальними навичками майбутніх лікарів на тлі належного рівня теоретикних знань $[2,3,5]$. Широке застосування в медичній освіті розвинених країн імітаційних методів навчання дозволило забезпечити зв'язок із важливими науковими та практикними завданнями відповідно із документом "Пріоритетними 
напрями (тематика) наукових досліджень та науково-теоретичних (експериментальних) розробок Національної академії педагогічних наук України на 2018-2022 рр". Використання освітніх програм на основі симуляційних технологій дозволяє підвищити професіоналізм медичного персоналу, що позитивно відбивається на якості надання медичної допомоги та догляду за пацієнтами.

Аналіз останніх досліджень i публікацій, в яких започатковано розв'язання цієї проблеми і на яких спирається автор. Ідеологія педагогічної підготовки в медичному вузі в даний час диктує вимоги щодо формування додаткових структурних підрозділів - імітаційних центрів, основною завдання яких $\epsilon$ навчання студентів практичним навичкам на фантомах, в умовах максимально наближених до реальної клінічної ситуації, залежно від конкретного призначення високотехнологічного симулятора [2], [3]. У світі накопичено значний досвід вузівської педагогічної роботи в області симуляції медичних маніпуляцій [4, 5]. Проте ряд аспектів організації навчальних симуляційних технологій медицини, методи їхнього застосування в підготовці майбутніх лікарів i оцінці якості засвоєння учнями мануальних навичок досі до кінця не розкриті. Залишаються неоднозначними судження на ряд таких питань, як: частота проведення занять, техніка і методологія навчання практичним навичкам, модель симуляції сценарію, параметри i критерії оцінки роботи студентів і ординаторів, стандартизація оціночних критеріїв знань і умінь здобувачів вищої освіти, їх уніфікованість і ряд інших.

Симуляція - це мистецтво імітувати реальність. Це може бути послідовність подій i дій або розумовий процес навчання якісному наданню медичної допомоги пацієнтам. Застосування симуляційних технологій медицини поширюється гранично швидко. Симуляційне навчання - один із ефек- тивних способів навчитися керувати помилками [4]. У даний час симулятори використовуються для навчання та об'єктивної оцінки осіб, що навчаються, в багатьох сферах діяльності, які передбачають високі ризики. Застосування симуляційного навчання - це прийнятний i необхідний напрям $\mathrm{y}$ навчальному процесі.

Наукові дослідження довели очевидну ефективність симуляційного навчання в порівнянні 3 традиційним [8]. Валідність, надійність і практичність клінічного іспиту була підтверджена й описана в багатьох дослідженнях, дані стали підставою для офіційного затвердження National Board of Medical Examiners (NBME) практики використання стандартизованих пацієнтів на IV-VI курсах навчання. Перше обов'язкове тестування студентів - медиків США (Клінічні навички - етап II) було виконано в 2004 р. як частина державної програми ліцензування [16].

Уже перші виконані дослідження N. Seymour [20], T. Grantcharov [12] показують переваги віртуальних тренажерів. За даними авторів, використання вір туального тренажера в навчальному процесі істотно (в 2,5 рази) знижує кількість помилок, які допускають початківці-хірурги при виконанні своїх перших лапароскопічних операцій. Результати досліджень підтверджують обгрунтованість триваючого впровадження імітаційних віртуальних технологій до програми медичного навчання та тренінгів. Реалістичність симуляційного обладнання (fidelity), що використовується для навчання медпрацівників, поділяється на сім рівнів [18]. При розробці тренажерів кожний наступний рівень складніше втілити в життя.

Віртуальні тренажери мають ряд безсумнівних переваг перед іншими варіантами навчання: немає поточних фінансових витрат, тривалість i режим навчання не обмежені за часом, можливо будь-яку кількість повторень вправи 3 
автоматичною, миттєвою i не упередженою якісною і кількісною оцінкою аж до досягнення його повного доведеного освоєння і закріплення, не потрібно постійної присутності викладача, методичні рекомендації здійнюються автоматично, програма сама вказує на допущені помилки, виконується об’єктивна сертифікація.

Симуляційні методики міцно увійшли до системи медичної освіти i стали невід'ємною частиною підготовки кадрів в сфері охорони здоров'я. У більшості освітніх установ 3'явилися нові структурні підрозділи - симуляційноатестаційні центри. За рахунок децентралізованого розвитку всі вони набули різної організаційної структури, спеціалізації, варіанти оснащеності, працюють за різними методиками і стандартами. В даний час в Україні функціонують десятки різноманітних імітаційних центрів, при цьому відсутня єдина класифікація - проста, зрозуміла, але, разом 3 тим, структурована, що відповідає практичним завданням медичної освіти. Вона повинна дати відправні точки для прийняття рішень про необхідність відкриття центру, вибір типу, спеціалізації, оснащеності i штатний розклад центру, точної постановки завдань i складання навчальних планів, затвердження методик i наділення повноваженнями.

Виділення не вирішених раніше частин загальної проблеми, котрим присвячується дана стаття. Використання освітніх програм на основі симуляційних технологій дозволяє підвищити професіоналізм медичного персоналу, що позитивно відбивається на якості надання медичної допомоги та догляду за пацієнтами. Отже, для забезпечення високої якості практичної підготовки студентів тільки наявності тренажерів недостатньо. Необхідно використання певних педагогічних технологій, що забезпечують спадкоємність системи відпрацювання та вдосконалення практичних навичок і підготовку до виконання професійної діяльності на всіх етапах навчання слухача.

Формулювання цілей статті

(постановка завдання.) Мета дослідження

- вивчення досвіду стимуляційного навчання з залученням "стандартизованих пацієнтів" як спосіб розвитку практичних вмінь у підготовці майбутніх лікарів.

Виклад основного матеріалу дослідження 3 повним обгрунтуванням отриманих наукових результатів. В системі медичної освіти симуляції лежать в основі ряду методик, покликаних відтворювати клінічні ситуації з метою навчання, повторення, оцінки i дослідження. Ці методики варіюють від базового рівня у вигляді вербальної симуляції до більш досконалих, таких, як стандартизований пацієнт. Використання освітніх програм на основі симуляційних технологій дозволяє підвищити професіоналізм медичного персоналу, що позитивно відбивається на якості надання медичної допомоги та догляду за пацієнтами. Головними перешкодами до цього є відсутність безперервного зворотного зв'язку між студентом і педагогом, неможливість практичної ілюстрації всього різноманіття клінічних ситуацій, а також моральноетичні та законодавчі обмеження в спілкуванні студентів із пацієнтом. Тому ключовим завданням сучасної середньої, вищої і післядипломної медичної освіти $€$ створення умов для розвитку в студентів широкого спектра компетенцій i міцно закріплених практичних навичок без ризику нанесення шкоди пацієнту. Так само як розвиток здатності швидкого прийняття рішень i бездоганного виконання ряду маніпуляцій або втручань, особливо при невідкладних станах [16].

У ВМНЗ України, у тому числі у Харківському національному університеті імені В. Каразіна, сьогодні створено симуляційно-тренінгові центри, де студенти мають змогу отримувати не тільки теоретичні знання, а й удосконалювати практичні навички, відпрацьовувати моделі поведінки медичного персоналу при лікуванні тих чи інших хвороб. Клінічні 
ситуації, які вимагають надання невідкладної допомоги за допомогою манекена можна відтворювати з будь-якою необхідною кількістю повторів в умовах, що повністю відповідають реальності. При цьому відбувається підготовка студентів до “зустрічі” з реальним пацієнтом.

Центри оснащені сучасним обладнанням для освоєння і вдосконалення базових і спеціальних умінь і навичок, $є$ можливість вдосконалення роботи в команді. Використовуються високотехнологічні віртуальні медичні тренажери, симулятори. Фантоми дозволяють відпрацювати до автоматизму навички надання невідкладної медичної допомоги. Тренервикладач може змоделювати будь-який сценарій. Це дозволяє не тільки виконувати стандартні навички надання допомоги, але на їхній основі тренувати клінічне мислення 3 динамічною оцінкою клінічної ситуації, у тому числі при відповіді на різні маніпуляції і лікарські препарати. Також на інтерактивному манекені реалізується міждисциплінарний підхід - при моделюванні сценаріїв 3 невідкладних станів, наприклад в акушерстві, “допомогу” одночасно надає “бригада лікарів" різних спеціальностей. Навчальне заняття може проходити за індивідуальним і командним або груповим, протоколами. За прийнятою методикою проводять брифінг і дебрифінг.

Дебрифинг (від англ. Debriefing обговорення після виконання завдання) $\epsilon$ одним із важливих етапів симуляційного навчання. Це наступний слідом за виконанням симуляційної вправи іiі розбір, обговорення набутого досвіду. Він активує рефлекссивне мислення студентів і забезпечує зворотний зв'язок для оцінки якості виконання імітаційних завдань i закріплення отриманих навичок і знань. Тому саме завдяки дебрифінгу симуляції досвід перетворюється в усвідомлену практику, яка допоможе тому, якого навчають підготуватися як емоційно, так i фізично до майбутньої професійної діяль- ності. На думку G. Salvoldelli і співавторів [19] проведення дебрифінгу значно підвищує ефективність симуляційніх занять із кризових ситуацій в анестезіології. В іншому дослідженні було встановлено, що включення дебрифінгу в симуляції навчання анестезіологів підвищувало ефективність навчання, а також тривалість збереження курсантами отриманих знань і навичок [20].

Клінічне моделювання дозволяє в реальному часі сформувати навик практичної роботи лікаря без наслідків для здоров'я людини. Заняття на спеціальних тренажерах дозволяють студентам відпрацювати базові діагностичні та лікувальні маніпуляції [13]. Впровадження сучасних тренажерних комплексів нового покоління, створення базових навчальних центрів, плавно перекидають місток від імітації в клініку до реального пацієнта. Важливим питанням для організації практичного навчання $є$ якісний $\mathrm{i}$ швидкий обмін інформацією між освітнім закладом і роботодавцем, забезпечення практичного заняття всіма необхідними ресурсами, ретельна постановка завдання навчання.

Змодельовані на комп'ютері ситуації активно реагують на дії студентів i повністю імітують фізіологічну відповідь пацієнта на дії лікаря або відтворюють адекватну реакцію тканин на маніпуляції хірурга. Крім того, комп'ютерне моделювання, засноване на об'єктивних даних реального пацієнта (МРТ, КТ, УЗД тощо) дозволяє заздалегідь спрогнозувати i навіть відпрацювати майбутнє дослідження або операцію, що знижує потенційний ризик i підвищує якість медичної допомоги [15]. Основний сенс симуляційного навчання в максимальній імітації всіх компонентів, які можуть бути задіяні в реальній життєвій ситуації, пов'язаній із лікуванням хворого в критичній ситуації.

Принципово новим став і педагогічний підхід до створення симулятора. Студент повинен усвідомлювати свою 
присутність в лікувальному середовищі, свій нерозривний зв'язок із оперованим пацієнтом, 3 його патологічним станом. Для цього лікувальні кейси реалізуються в вигляді задач, в яких пропонується не тільки виконати технічні дії, але необхідно оцінити клінічну ситуацію, прийняти вірне тактичне рішення. Дії оператора-симулятора не просто змінюють віртуальні тканини, він погіршує стан віртуального пацієнта, провокує розвиток у нього ускладнень, з якими далі доведеться боротися. Це, безсумнівно, підвищує реалізм симуляції і значимість такого навчання в цілому.

Існує наочний інструмент для оцінки прогресу студента (ординатора) від новачка до експерта. На самому нижчому рівні, у студента $є$ освоєне знання, яке він може використовувати для вирішення тестів і на письмових або усних іспитах. У стадії “знає як” (know how), вони можуть використовувати свої знання в більш складних за формою проведення іспитах, які вимагають застосування знань. У стадії “показує як (демонструє)" (show how), вони можуть продемонструвати свої навички в симульо-ваних умовах або на сертифікаційних іспитах. Але тільки в стадії "робить" (does) вони використовують свої навички на практиці [10].

Впровадження контролю рівня підготовленості через систему симуляції навчання, обов'язкового етапу атестації в умовах симуляційного навчання для кожного студента і стажиста могло б сприяти вирішенню проблеми сертифікації кадрів. При цьому загальновизнано, що процес такого контролю не повинен носити каральний характер, а основні зусилля слід спрямувати на сприяння професійному розвитку, виявлення обмежень і зниження ризику, який може нести погано підготовлений лікар або медична сестра.

Накопичений досвід симуляційного навчання в країні дозволяє, передусім, переконатися в безперечних перевагах симуляційного тренінгу:

- клінічний досвід у віртуальному

середовищі без ризику для пацієнта;

- об'єктивна оцінка досягнутого рівня майстерності;

- необмежена кількість повторів

відпрацювання навичок;

- тренінг у зручний час, незалежно від роботи клініки;

- відпрацювання дій при рідкісних патологіях i патологіях, що загрожують життю;

- передача частини функцій викладача віртуальному тренажеру;

- підвищення ефективності навчання медичних фахівців новим високотехнологічним методикам, а також нових процедур в рамках методик, що вже практикуються;

- зниження стресу при перших самостійних маніпуляціях [7].

Таким чином, віртуальний симулятор, звичайно, не підміняє традиційні форми навчання - лекцію, семінар, перегляд відео та мультимедійних матеріалів, курацію хворих і т.д., однак, до того, як допустити лікаря до пацієнта, необхідно відпрацювати практичні вміння на тренажері і сертифікувати отримані навички. Вищесказане підтверджується дослідженнями зарубіжних колег, які показують, що фахівці високо оцінюють можливість брати участь в симуляції навчання. Незважаючи на почуття напруги, а іноді і справжнього стресу при роботі з таким “важким пацієнтом”, вони вважають за краще бачити безпосередні результати виробленого лікування, а не просто читати про них у підручниках або слухати на лекціях. Найбільше, як показує опитування, фахівці цінують можливість робити помилки і вчитися на них в безпечному освітньому середовищі [8]. Але для цього необхідно створення таких сучасних імітаційних центрів, можливо, в рамках клінікоосвітнього кластера. Іншою формою симуляційного навчання в сфері викладання хірургічних хвороб, не менш 
складній для практичної реалізації, можуть стати “стандартизовані пацієнти”, що $є$ кращою альтернативою реальним хворим. Вони стандартно можуть виконувати роль пацієнта, включаючи психологічні та фізіологічні аспекти.

Симуляційні навчання повинні проводитися спеціально навченими штатними інструкторами (викладачамитренерами, навчальними майстрами), які спільно 3 практикуючими фахівцями (експертами) будуть створювати і накопичувати багаж різних сценаріїв, вести методичну роботу, а також спільно 3 технічними працівниками розробляти i підтримувати в робочому i безпечному стані засоби навчання (програмне забезпечення, комп'ютери, тренажери, симулятори, фантоми, моделі i професійне обладнання) на основі системи інженернотехнічного обслуговування i постачання витратних матеріалів. У зв'язку 3 залученням великої кількості фахівців вузу до реалізації імітаційного навчання підвищується загальний рівень готовності співробітників до впровадження віртуальних технологій у педагогічний процес, модернізується мислення в цілому, удосконалюються i збагачуються педагогічні підходи викладачів.

Робота навчально-практичного тренінгового центру Харківського національного університету імені В. Каразіна, який функціонує з 2013 року в його структурі, показала необхідність даного навчання i, за результатами анонімного анкетування, було отримано позитивні відгуки серед багатьох студентів, які пройшли навчання у цьому центрі. На їхню думку, використання манекенів i симуляторів у навчальному процесі має більший ефект, ніж просто лекційний формат навчання.

Під час проходження практики студентами кафедри хірургічних хвороб був проведений аналіз ефективності симуляційного тренінгу 3 залученням “стандарти зованого пацієнта". Суть методу полягає в тому, що в ролі пацієнта виступає спеціально навчений актор, здатний з великим ступенем вірогідності інсценувати той чи інший клінічний випадок. Він має конкретні установки від методиста-інструктора, які забороняють імпровізувати щодо основної сюжетної лінії i покликані видавати чітко сформульовану інформацію за розробленим для актора сценарієм. Спочатку видаються скарги, як і вся інша частина легенди (анамнезу), вони будуть деталізовані тільки в разі відповідних конкретних питань із боку студента. У той же час наявна 3 тієї чи іншої задачі патологія формується не тільки за рахунок сценічних словесних образів, але й шляхом демонстрації акторами тих чи інших симптомів при об'єктивному обстеженні. Додатковий внесок у створення реалістичного образу хворої людини вносить використання результатів методів дослідження, карток із функціональними показниками.

Тренінг із залученням “стандартизованого пацієнта" проводиться в навчальній кімнаті, в якій створені умови, наближені до реального амбулаторного кабінету лікаря. Студентам було надано усі необхідні матеріали: медична кушетка, стільці, письмовий стіл, тонометр, фонендоскоп, амбулаторна картка, направлення на госпіталізацію, рецептурні бланки. В окремій папці - ультразвукове дослідження органів черевної порожнини, ЕКГ плівка, результати клінічного аналізу крові, сечі, біохімічного аналізу крові, сечі, (адаптовані до клінічної ситуації, що розглядається). Студентам був представлений стандартизований пацієнт - актора чоловічої статі, 48 років, який заздалегідь пройшов підготовку та був готовий “симулювати” клінічну картину захворювання i давати адекватні відповіді на питання, що ставляться лікарем в ході збирання скарг, анамнезу та огляду. За роботою лікаря дистанційно спостерігали 2 викладача кафедри.

Викладачі кафедри, що спостерігали за оглядом стандартизованого 
пацієнта оцінювали послідовність, повноту та якість дій студента під час збору скарг, анамнезу, об'єктивного огляду, адекватність аналізу даних додаткових методів обстеження та тактики поодальшого ведення хворого (медикаментозні призначення, загальні рекомендації, госпіталізація, показання до хірургічного лікування). Після тренінгу проводиться детальний розбір результатів роботи студента, спільне обговорення помилок та інші заходи, спрямовані на покращення лікувально-діагностичної тактики. Оцінка основних етапів роботи лікаря 3 пацієнтом проводилась за бальною системою, відповідно до критеріїв. Максимальна оцінка 100 балів.

На початку тренінгу було проведено оцінку теоретичних знань майбутніх лікарів із питань клінічної діагностики та фармакотерапії хірургічних хворих за допомогою тестових завдань КРОК-2 за минулі роки. За результатами більша частина студентів мала дуже низькі бали 3 теоретичних питань (70\% не дали $60 \%$ правильних відповідей, $15 \%$ - дали правильних відповідей, менше $50 \%$ відсотків та лише 15\% продемонстрували хороші та відмінні знання). Наприкінці тренінгу було проведено анкетування 33 студентів за розробленою анкетою. За даними дослідження найбільші ускладнення майбутні лікарі відчували під час проведення обстеження (36,4\%), диференціальної діагностики хвороби (22\%) i під час складання програми лікування (40\%).

Самі здобувачі вищої освіти бачили причини такої обставини в нестачі власних теоретичних знань (у 54\%). За даними анкетування, стимуляційний тренінг із питань клінічної діагностики та фармакотерапії хірургічних хворих допоміг у засвоєнні знань та навичок 72,3\% майбутніх лікарів (див. рис. 1).

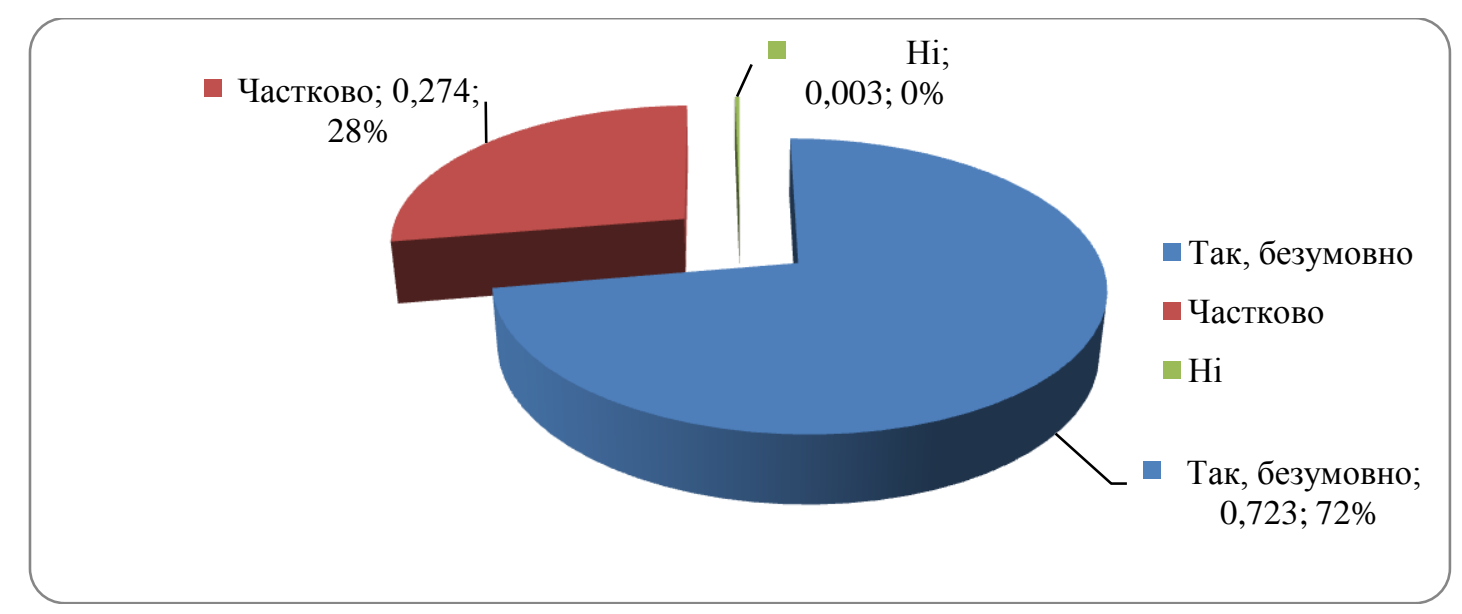

Рис. 1 - Результати опитування слухачів щзодо засвоєння знань та навичок під час проведення тренінгу.

У процесі тренінгу студент вчиться застосовувати свої теоретичні знання на практиці, користуючись ними, як інструментами в досягненні конкретної мети допомога хворій людині. Причому протягом всього заняття він зайнятий проблемою однієї реальної людини, а не абстрактного випадку, позбавленого індиві- дуальності та специфічності. Після проходження тренінгу 3 використанням методики “Стандартизований пацієнт" 71\% студентів відзначили, що їм стало легше спілкуватися 3 пацієнтами та покращилися практичні навички самостійної роботи. У процесі спілкування з пацієнтами студенти відточують навички опитування та обсте- 
ження, знайомляться 3 різними лабораторно-інструментальними даними, вчаться заповнювати історії хвороби, вирішувати ситуаційні завдання, проводити диферентціальну діагностику. Таким способом вони готуються до того, що нерідко доведеться лікувати 2 хвороби одночасно, шукати адекватні підходи до лікування декількох різнопланових патологій. Отже, цінність методики “Стандартизований пацієнт”, на наш погляд, очевидна: по-перше, студент має можливість відпрацювати практичні навички на реальному пацієнті, а в разі помилок виправити наявні недоліки. Подруге, він вчиться працювати самостійно, один на один із хворим, покладаючись тільки на свої сили і знання. По-третє, студент звикає працювати в умовах суворо обмеженого часу (20 хв. опитування, 25 хв. огляд), дефіцит якого є однією 3 реалій трудових буднів лікаря будь-якої спеціальності. Крім того, у майбутніх лікарів $є$ можливість відпрацювати і психологічні основи взаємодії “лікар-пацієнт”.

Незважаючи на велику кількість достоїнств і переваг цього методу, може виникнути цілком планомірне питання: для чого влаштовувати трудомісткий процес, якщо таку можливість можна реалізувати в умовах установ практичної охорони здоров'я (стаціонарах, поліклініках). У цьому контексті необхідно зупинитися на проблемі гуманізму i захисту особистості як такої i хворої людини зокрема. В економічно розвинених країнах це питання давно вирішене і чітко відтворене у навчальних програмах, що носять загальнонаціональний державний характер. Навчання майбутнього лікаря починається 3 тренажерів i муляжів, а на старших курсах триває на імітаційних іграх за участю добровольців. Питання етичного плану в даному випадку вирішується шляхом установки договірних відносин між зво i акторами, підкріпленими відповідними документами та фінансовою винагородою. Слід зазначити, що в ролі актора можуть виступати як професійні артисти, так і просто творчо обдаровані люди.

За результатами дослідження, можна зробити висновок, що метод “стандартизованих пацієнтів" є ефективним та якісним методом оцінювання клінічної компетентності. Він має кращі психометричні властивості, ніж традиційні засоби оцінювання студентів біля ліжка хворого. Світове поширення цього методу 3 метою навчання та оцінювання підтверджує, що його переваги більші, ніж недоліки та обмеження, а також свідчать про прийнятність його апробації в Україні. Цілком природно i те, що дискусія про впровадження "стандартизованих пацієнтів” викликає посилання на переваги реальних хворих.

Використання "стандартизованих пацієнтів" має багато переваг над використанням справжніх хворих та штучних стимуляторів. Зокрема це дає можливість:

- забезпечити уніфіковане, точне та надійне подання та демонстрацію багатьох медичних проблем для великої кількості студентів;

- уніфікувати поведінку хворих під час іспиту;

- контролювати складність клінічного тесту;

- контакту зі студентами;

- оцінки роботи студента в складних етичних умовах;

- забезпечити високе задоволення студентів від складання клінічного іспиту у такій формі.

Висновки 3 даного дослідження та перспективи подальших розвідок у даному напрямку. У світлі актуальних проблем сучасної охорони здоров'я стає очевидним, що необхідно не тільки активно шукати нові шляхи щодо підвищення якості освіти медиків, але більш широко впроваджувати перспективні нововведення в структуру навчально-методичного процесу. Особливу увагу слід приділяти методам активного навчання та контролю, які $\epsilon$ 
МАЙСТЕРНОСТІ МАЙБУТНІХ ФАХІВЦІВ

найбільш дієвими і результативними. Використання симуляційних технологій у процесі навчання дозволяє студентаммедикам набувати практичного досвіду і якісно підвищувати рівень свого професіоналізму на тлі належного рівня теоретичних знань. У той же час вони жодною мірою не повинні бути протиставлені традіцийній системі клінічної підготовки. Тільки їхнє адекватне поєднання здатне реально підвищити освітній рівень випускників вищих медичних закладів, а практичну охорону здоров'я забезпечити висококваліфікованими фахівцями.

Результати дослідження підтверджують обгрунтованість впровадження

\section{Список літератури:}

1. Балл Г. Перепелиця П. С., Рибалко В. В. Психологія праці та професійної підготовки особистості: навч. посібник / Г. Балл, П. С. Перепелиця, В. В. Рибалко // Академія педагогічних наук України; Інститут педагогіки i психології професійної освіти Хмельницький: Універ. - 2001. - С. 330

2. Горшков М. Д. Подразделение симуляционно-аттестационных центров на три уровня / М. Д. Горшков // Виртуальные технологии в медицине. - 2013. - №2 (10). - C. $24-27$

3. Осанова М. В., Тимербаев В. Х. , Валетова В. В., Зверева Н. Ю. Опыт реализации симуляционных образовательных программ последипломного обучения врачей в неотложной медицине и анестезиологии / М. В. Осанова, В. Х. Тимербаев, В. В. Валетова, Н. Ю. Зверева // Медицинское образование и профессиональное развитие. - 2011

4. Пасечник И. Н., Скобелев Е. И., Алексеев И. Ф., Блохина Н. В., Липин И. Е., Крылов В. В. Роль современных симуляционных технологий в подготовке анестезинлогов-реаниматологов с учетом пропедевтики и квазифизиологических особенностей роботов-симуляторов / симуляційних віртуальних технологій до програми медичного навчання та ефективність тренінгів. Залишаються неоднозначними судження щодо питань: частота проведення занять, техніка i методологія навчання практичним навичкам, модель симуляції сценарію, параметри і критерії оцінки роботи студентів $\mathrm{i}$ ординаторів, стандартизація оціночних критеріїв знань і умінь здобувачів вищої освіти, їх уніфікованість і ряд інших. Як перспектива подальших розвідок необхідними $\epsilon$ розробка методичних рекомендацій проведення тренінгу, спрямованих на покращення лікувальнодіагностичної тактики та отриманих помилок.

И. Н. Пасечник, В. В. Крылов И. Е. Липин, Е. И. Скобелев, И. Ф. Алексеев, Н. В. Блохина, // Тезисы докладов. 1-й конференции по симуляционному обучению в медицине критических состояний с международным участием. - 1 ноября 2012. - М.; - 2012. - C. 7-73

5. Пасечник И. Н., Блашенцева С.А., Скобелев Е. И. Симуляционные технологии в анестезиологии-реаниматологии: первые итоги / И. Н. Пасечник, С. А. Блашенцева, Е. И. Скобелев // Виртуальные технологии в медицине. - 2013. - №2(10). - С. 16-21

6. Пометун О. І., Пироженко Л. В. Сучасний урок / O. I. Пометун, Л.В.Пироженко // Інтерактивні технології навчання. - К.: А.С.К. - 2004. - С. 192

7. AhlbergU.G.,EnochssonL.,Hedman L.,Hogman C., Gallagher A., Ramel S., Arvidsson D. / Обов'язкова підготовка тренажерів для мешканців перед виконанням лапа рос-копічної холецистектомії? // Це 13-й Конгрес EAES. Венеція, Лідо, Італія, 1-4 червня 2005 p. Surg Endosc. - Квітень 2006 р. - 20 Додатково. 1. - С. 18-20

8. Купер Дж. Б., Такеті В. Р. Коротка історія розвитку тренажерів-манекенів для клінічної освіти та навчання / Дж. Б. Купер, В. Р.Такеті // Післядипломний медичний журнал. - 2008. - № 84 (997). - С. 563-570

9. Крістіан К. К., Густафсон М. Л., 
Рот Е. М. та ін. Проспективне дослідження безпеки пацієнтів в операційній /К.К. Крістіан, М. Л. Густафсон, Е. М. Рот. Хірургія. - 2006. - 139. - С. 159-173

10. Dongen K.W., Zee D.C., Broeders

I.A.M.J. Чи може симулятор віртуальної реальності розрізняти різні рівні досвіду в ендоскопічній хірургіï? / K.W. Dongen, Zee D.C., Broeders I.A.M.J. B: Тези 13-й Конгрес EAES. Венеція, Лідо, Італія, 1-4 червня 2005 р. Surg Endosc. - Квітень 2006. -20 доп. 1:54. - С. 8

11. Гаванде А. А., Циннер М. Дж., Стаддерт Д. М., Бреннан Т. А. Аналіз помилок, про які повідомили хірурги у трьох навчальних лікарнях / А. А. Гаванде, М. Дж.Циннер, Д. М. Стаддерт, Т. А. Бреннан. - Хірургія. - 2003. - №133. - С. 614-621

12. Grantcharov T., Aggarwal R., Eriksen J.R., Blirup D., Kristiansen V., Darzi A., Funch-Jensen P. Комплексна програма навчан-ня віртуальної реальності 3 лапароскопічної хірургії. Тези 13 конгресу EAES. Венеція, Лідо, Італія, 1-4 червня 2005 p. Surg Endosc. - Квітень 2006. - №20 доп. 1. - С. $38-40$

13. Hallikainen H., Väisänen $O$., Randell T. et al. Викладання введення анестезії для студентів-медиків: порівняння між повно масштабним моделюванням та викладанням під керівництвом в операційній / H. Hallikainen, O. Väisänen, T. Randell // Євро. Дж. Анаст. - 2009. -№ 26. - C. 101-104

14. Hassan I., Sitter H., Schlosser K., Zielke A., Rothmund M., Gerdes B. Симулятор віртуальної реальності для об'єктивної оцінки лапароскопічної майстерності хірургів / I. Hassan, H. Sitter, K. Schlosser, A. Zielke, M. Rothmund, B. Gerdes. - Хірургія. - Лютий 2005. - №72 (2):151. - C. 5

15. Holcomb J. B., Dumire R. D., Crommett J. W. та ін. Оцінка роботи групи травматологів за допомогою передового тренажера пацієнта для реанімації / J. B., Holcomb, R. D. Dumire, J. W. Crommett. - Дж. Травма. - 2002. - №
52:1078. - C. 85

16. Міллер Г. Е. Оцінка клінічних на-вичок, компетентності, результативності / Г. Е. Міллер. - Акад. Мед. - 1990. - 65(9). -C. 63-67

17. Narreddy R., Carter F.J., Cuschieri A. В: Тези 13-й Конгрес EAES. - Венеція, Лідо. - Surg Endosc. - 2006. - №20. - доп.1. -C. $13-15$

18. Peters V.A.M., Vissers G.A.N. Проста класифікаційна модель для аналізу симуляційних ігор / V.A.M. Peters, G.A.N. Vissers // Simul. Ігровий березень. - 2004. № 35 (1). - C. 70-84

19. Savoldelli G.L., Naik V.N., Park J. et al. Значення аналізу під час модельованого управління кризою: усний або усний відгук за допомогою відео / G. L. Savoldelli, V. N. Naik, J. Park // Нешезіологія.-2006.-№105:279. - С. 85

20. Сеймур Н. Е., Галлахер А. Г., Роман С. А., О’Браєн М. К., Бансал В. К., Андерсен Д. К., Сатава Р. М. Навчання віртуальній реальності покращує продуктивність операційної: результати рандомізованого подвійного сліпого дослідження / Сеймур Н. Е. та ін. - Енн Сург. - 2002.- №236 (4):458. С. 64

\section{References:}

1. Ball, H. Perepelytsia, P. S., Rybalko, V. V. (2001), "Psychology of work and professional training of the person: textbook. Manual", Academy of Pedagogical Sciences of Ukraine; Institute of Pedagogy and Psychology of Vocational Education, Khmelnytsky:Uni-ty,p. 330

2. Horshkov, M.

D. (2013), "Subdivision of simulation and certification centers into three levels", Virtual technologies in medicine, no. 2(10), pp. 24-27

3. Osanova, M. V., Tymerbaev, V. Kh., Valetova, V. V., Zvereva, N. Iu. (2011), "Experience in the implementation of simulation educational programs for postgraduate training of doctors in emergency medicine and anesthesiology", Medical education and professional development 
4. Pasechnyk, Y. N., Skobelev, E. Y., Alekseev, Y. F., Blokhina, N. V., Lipin, Y. E., Krylov, V. V. (2012), "The role of modern modeling technologies in the training of anesthesiologists-resuscitators taking into account propaedeutics and quasiphysiological characteristics of robotic simulators", Abstracts. 1st conference call on simulation training in critical care medicine with international participation, November 1, 2012, M., pp. 7-73

5. Pasechnyk, Y. N., Blashentseva, S.A., Skobelev, E. Y. (2013), "Simulation techno-logies in anesthesiology and resuscitation: first results", Virtual technologies in medicine, no. 2:10, pp.16-21

6. Pometun, O. I., Pyrozhenko, L.V. (2004), "A lucky lesson. Interactive technologies for the creation", K.: A.S.K., p. 192 7. Ahlberg, U. G., Enochsson, L., Hedman, L., Hogman, C., Gallagher, A., Ramel, S., Arvidsson, D. (2005), "Compulsory simulator training for residents prior to performing laparoscopic cholecystectomy?", Abstracts 13th EAES Congress, Venice, Lido, Italy, 1-4 June 2005, Surg Endosc, 2006 Apr; 20 Suppl, no. 1, pp. 18-20

8. Cooper, J. B., Taqueti, V. R. (2008), "A brief history of the development of mannequin simulators for clinical education and training", Postgraduate medical journal, no. 84 (997), pp. 563-570

9. Christian, C. K., Gustafson, M. L., Roth, E. M. et al. (2006), "A prospective study of patient safety in the operating room", Surgery, no. 139, pp. 159-173

10. Dongen, K. W., Zee, D. C., Broeders, I.A.M.J. (2005), "Can a virtual reality simulator distinguish between different experience levels in endoscopic surgery?", In: Abstracts 13th EAES Congress. Venice, Lido, Italy, 1-4 June 2005. Surg Endosc. 2006 Apr; 20 suppl, no. 1:54 p. 8

11. Gawande, A. A., Zinner, M. J., Studdert, D. M., Brennan, T. A. (2003), "Analysis of errors reported by surgeons at three teaching hospitals", Surgery, no. 133, pp. 614-621

12. Grantcharov, T., Aggarwal, R.,
Eriksen, J. R., Blirup, D., Kristiansen, V., Darzi, A., Funch-Jensen, P. (2005), “A comprehensive virtual reality training program for laparoscopic surgery", Abstracts 13th EAES Congress. Venice, Lido, Italy, 1-4 June 2005, Surg Endosc, 2006 Apr; 20 suppl, no.1, pp. $38-40$

13. Hallikainen, H., Väisänen, O., Randell, T. et al. (2009), "Teaching anaesthesia induction to medical students: comparison between full-scale simulation and supervised teaching in the operating theatre", Eur. J.Anaesth., no. 26, pp. 101-104

14. Hassan, I., Sitter, H., Schlosser, K., Zielke, A., Rothmund M., Gerdes, B. (2005), "A virtual reality simulator for objective assessment of surgeons laparoscopic skill", Chirurg, feb no. 72(2):151, p. 5

15. Holcomb, J. B., Dumire, R. D., Crommett, J. W. et al. (2002), "Evaluation of trauma team performance using an advanced human patient simulator for resuscitation training", J. Trauma., no. 52:1078, p. 85

16. Miller, G. E. (1990), "The assessment of clinical skills, competence, performance", acad. med., no. 65(9), pp.63-67

17. Narreddy, R., Carter, F. J., Cuschieri, A. (2006), "Evaluation of the effect of feedback on surgical task performance on a virtual reality laparoscopic simulator", In: Abstracts 13th EAES Congress, Venice, Lido. Surg Endosc. Apr; 20 suppl,no.1, pp.13-15

18. Peters, V.A.M., Vissers, G.A.N. (2004), "A simple classification model for debriefing simulation games", Simul, Gaming March, no. 35(1), pp. 70-84

19. Savoldelli, G. L., Naik, V. N., Park, J. et al. (2006), "Value of debriefing during simulated crisis management: oral versus video-assisted oral feedback", Neshesiology, no. $105: 279$ p. 85

20. Seymour, N. E., Gallagher, A. G., Roman, S. A., O’Brien, M. K., Bansal, V. K., Andersen, D. K., Satava, R. M. (2002), "Virtual Reality Training Improves Operating room performance: Results of a randomized, double-blinded Study", Ann Surg, no. 236(4):458, p. 64

Стаття надійшла до редколегї̈ 26.08.2021 